\title{
Rancang Bangun VVVF Inverter 3 Fasa untuk Operasi Motor Induksi Tiga Fasa dengan Antarmuka Komputer
}

\author{
Fitrah Hidayat $^{1^{*}}$ dan Krismadinata ${ }^{1}$ \\ ${ }^{1}$ Jurusan Teknik Elektro, Fakultas Teknik, Universitas Negeri Padang \\ *Corresponding author, e-mail: dhayaik90@gmail.com
}

\begin{abstract}
Abstrak - Pemanfaatan elektronika daya saat ini banyak digunakan pada industriindustri, sebagai perangkat utama pada energi terbarukan, maupun pada kebutuhan rumah tangga. Salah satu dari banyak nya perangkat elektronika daya yang digunakan adalah inverter. Terkhususnya pada industri, sebuah inverter dapat berguna sebagai pemasok sumber tegangan AC dari pembangkit industri yang bersumber DC, maupun untuk pengontrolan motor induksi baik itu satu fasa maupun tiga fasa. Inverter 3 fasa ini bertujuan untuk pengoperasian motor induksi 3 fasa, dengan cara memvariasikan tegangan dan frekuensi keluaran dari inverter tersebut. Metode yang digunakan adalah metode pembangkitan SPWM atau sinusoidal pulse width modulation. Metode ini dipilih dengan pertimbangan lebih mudah diterapkan, dapat membuat gelombang keluaran lebih halus / atau jelas, dan mendekati hasil gelombang keluaran yang diharapkan, yakninya sinusoidal. Selain digunakan pada industri, inverter ini juga dapat digunakan sebagai perangkat utama dari energi terbarukan maupun untuk penggunaan pada rumah tangga. Perancangan inverter ini terdiri dari hardware dan software. Hardware terdiri dari Arduino Mega, rangkaian Gate Driver, Catu Daya, Rangkaian MOSFET Bridge 3 Fasa, dan Rangkaian Filter. Adapun untuk perancangan software menggunakan VB.Net. Untuk pengujian, pertama kali dilakukan pengukuran pada bagian input dan output dari masingmasing blok rangkaian. Selanjutnya dilakukan pengujian dengan menggunakan potensiometer dan monitoring dengan VB.Net.
\end{abstract}

Kata Kunci : Inverter 3 Fasa, Motor Induksi, Arduino Mega, Gate Driver, MOSFET Bridge 3 Fasa, Personal Computer

\begin{abstract}
Utilization of power electronics is widely used in industries, as the main device in renewable energy, as well as in household needs. One of the many power electronics devices used is an inverter. Especially in the industry, an inverter can be used as a supplier of AC voltage sources from industrial plants that are sourced from DC, also for controlling induction motors both single phase and three phase. This 3 phase inverter for 3 phase induction motor operation, by varying the output voltage and frequency of the inverter. The method used is the SPWM generation method or sinusoidal pulse width modulation. The method chosen with considerations that are easier to implement. This method can make the output wave finer / clearer, with the expected sinusoidal output waveform. Apart from being used in industry, this inverter can also be used as the main device of renewable energy and also for household use. The design of this inverter consists of hardware and software. The hardware consists of Arduino Mega, Gate Driver circuit, Power Supply, 3 Phase Bridge MOSFET Circuit, and Filter Series. As for designing software using Arduino IDE and VB.Net. For testing, the first step is testing the input and output sections of each circuit block. Next is using potentiometers and monitoring with VB.Net.
\end{abstract}

Keywords: 3 Phase Inverter, Induction Motor, Arduino Mega, Gate Driver, 3 Phase MOSFET Bridge, PC (Personal Computer) 


\section{Pendahuluan}

Kebutuhan akan energi dan pengendalian sangat dibutuhkan oleh masyarakat dan industri. Dikarenakan kebutuhan energi yang tinggi, manusia mulai mencari sumber energi alternatif. Beberapa contoh dari sumber energi tersebut adalah microhidro, photovoltaic/solar cell, wind turbine, pv/wind hybrid system, dan lain sebagainya [1].

Energi listrik yang diperoleh dari sumber energi tersebut, masih berupa sumber teganngan DC (Direct Current). Sedangkan peralatan elektronik yang digunakan masyarakat dan peralatanperalatan di industri, umumnya menggunakan sumber tegangan AC (Alternating Current). Sedangkan pada industri, juga dibutuhkan peralatan pengontrolan pengoperasian motor dengan kualitas yang baik, terkhususnya motor induksi.

Sebuah inverter yang berkualitas baik dibutuhkan untuk mengubah sumber tegangan DC ke sumber tegangan AC yang mampu digunakan baik untuk pemakaian sehari-hari oleh masyarakat maupun pengoperasian motor induksi bagi industri. Sebuah inverter yang berkualitas baik, adalah inverter yang memiliki persen Total Harmonic Distortion (THD) dibawah 5\%. Karena itu, dipilih lah sebuah metode pengontrolan inverter, yaitu dengan metode Pulse Width Modulation (PWM). Output dari sebuah inverter yang menggunakan metode PWM, dengan melakukan beberapa filter, hampir dapat memenuhi spesifikasi THD yang diperbolehkan dibandingkan dengan metode skema pensaklaran inverter gelombang kotak [2].

Perancangan inverter ini memiliki tipe Voltage Source Inverter (VSI) 3 fasa, yang berbeda 120 derajat pada tiap fasanya, menggunakan metode Sinusoidal Pulse Width Modulation (SPWM), dengan keluaran tegangan dan frekuensi yang dapat divariasikan. SPWM adalah sebuah metode pembangkitan PWM yang membentuk sinusoidal, yang memiliki banyak variasi duty cycle pada satu sinyal PWM [3]. Untuk mendapatkan tegangan keluaran yang dapat divariasikan, cukup dengan mengubah besarnya duty cycle sinyal PWM yang dibangkitkan tersebut. Sedangkan untuk frekuensi yang dapat divariasikan, dapat dilakukan dengan cara mengubah jarak antara satu duty cycle dengan duty cycle lainnya.

Keluaran dari inverter nantinya diteruskan ke beban berupa motor induksi 3 fasa. Untuk operasi motor induksi 3 fasa, pengaturan kecepatan dari motor dapat dilakukan dengan cara memvariasikan frekuensi keluaran dari inverter.

\section{INVERTER TIGA FASA}

Inverter merupakan suatu rangkaian elektronika yang mengkonversi sumber tegangan DC menjadi sumber tegangan AC. Sebuah inverter disupplai dari sebuah sumber DC dimana output tegangan dan arus AC-nya mempunyai komponen fundamental dengan frekuensi dan amplitudo yang dapat divariasikan [4].

Komponen utama dari rangkaian inverter, biasanya memerlukan komponen semikonduktor pensaklaran berupa MOSFET, IGBT, maupun SCR. Untuk rangkaian inverter 3 fasa, memerlukan 6 komponen semi konduktor untuk membuat bridge inverter 3 fasa. Pada gambar 1 diperlihatkan rangkaian inverter 3 fasa.

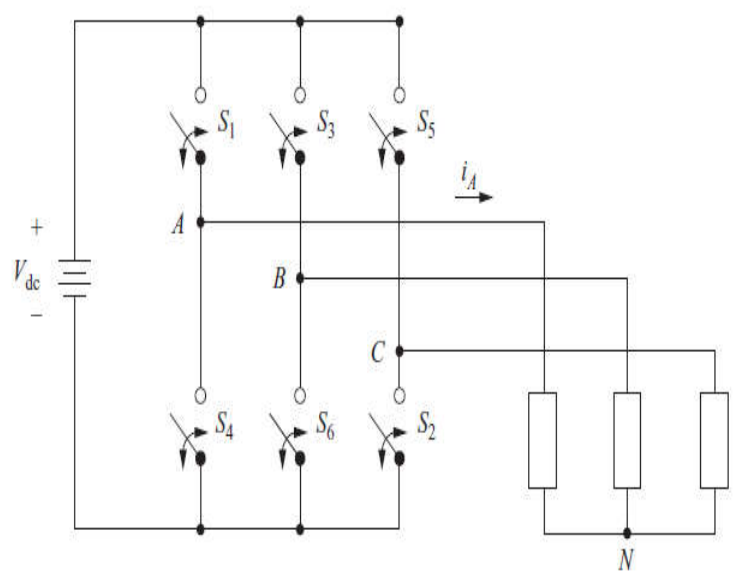

Gambar 1. Rangkain inverter 3 fasa

Dari gambar 1, dimisalkan komponen semikonduktor yang diberikan adalah MOSFET, kaki drain MOSFET S1 terhubung ke terminal positif dari sumber tegangan DC dan kaki source MOSFET S4 terhubung ke terminal negatif dari sumber tegangan DC, sedangkan kaki source MOSFET S1 terhubung ke kaki drain MOSFET S4. Begitu juga dengan MOSFET S3 dengan MOSFET S6, dan MOSFET S5 dengan MOSFET S2. Pertemuan kaki source MOSFET dengan kaki drain MOSFET lainnya akan menghasilkan terminal untuk fasa. Dari gambar diatas dapat dilihat fasa A dihasilkan dari MOSFET S1 dengan S4, fasa B dihasilkan dari MOSFET S3 dengan S6, dan fasa C dihasilkan dari MOSFET S5 dengan S2.

Metode pengontrolan dari inverter juga bervariasi, salah satunya adalah metode pengontrolan menggunakan SPWM. Metode ini dipilih karena dipandang bagus untuk meredam THD dan menghasilkan output gelombang sinus yang baik. Pada gambar 2 dapat dilihat ilustrasi pembangkitan sinyal SPWM 3 fasa dengan metode pembangkitan analog. 


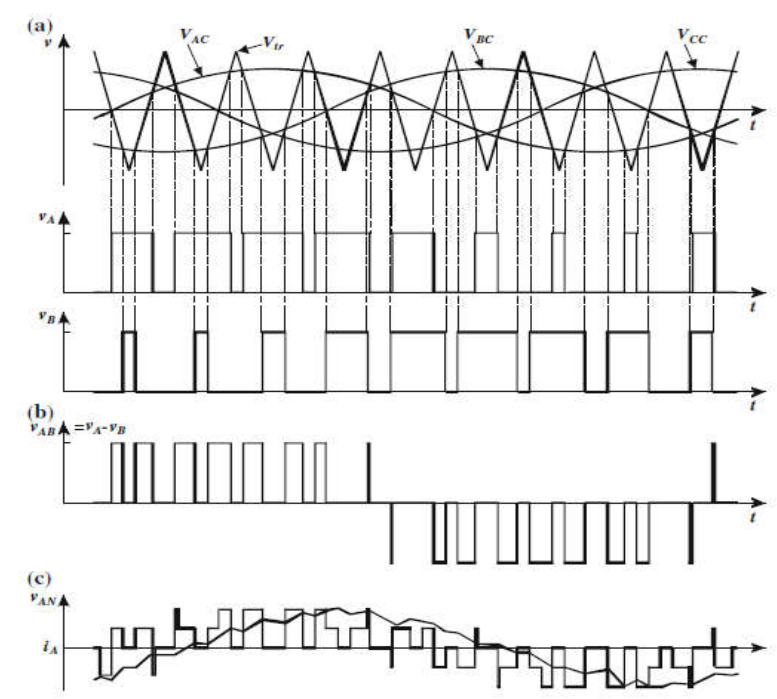

Gambar 2. Metode Pembangkitan SPWM 3 Fasa

Untuk pembangkitan sinyal SPWM secara analog seperti pada gambar di atas, dapat diperhatikan untuk menghasilkan sinyal SPWM 3 fasa, dibutuhkan tiga sinyal referensi sinusoidal dan satu sinyal carrier triangular, yang mana tiaptiap sinyal referensi dibandingkan dengan sinyal triangular didalam sebuah komparator. Apabila sinyal referensi lebih besar nilainya daripada sinyal segitiga, maka output PWM nya akan bernilai high, sedangkan jika sinyal referensi lebih kecil nilainya daripada sinyal segitiga, maka output PWM nya akan bernilai low. Semua yang dimaksudkan untuk inverter ini beroperasi pada frekuensi dari sinyal carrier, oleh karena itu komponen saklar harus memiliki spesifikasi untuk frekuensi tinggi [5].

Untuk pembangkitan SPWM secara digital, dapat menggunakan sebuah mikrokontroler dengan metode pemograman membuat sebuah lookup table yang terdiri dari kumpulan data array, tiaptiap nya mempunyai nilai berbeda duty cycle. Duty cycle tersebut memiliki karakteristik bernilai rendah diawal data, bernilai tinggi di tengah data, dan bernilai rendah lagi pada akhir data. Sehingga dapat dikatakan look up table tersebut merepresentasikan sebuah sinus.

\section{A. Gate Driver}

Sebuah gate driver adalah rangkaian penguat tegangan yang memperoleh tegangan input yang kecil dari sebuah kontroler dan menghasilkan tegangan input yang lebih besar, sehingga dapat diinputkan ke rangkaian yang memiliki komponen utama semikonduktor seperti SCR, IGBT atau MOSFET. Ilustrsi ini dapat dilihat pada gambar 3.

Gate driver sangat berguna untuk rangkaian konversi daya seperti rectifier, inveter, dan DC-DC konverter seperti buck ataupun boost konverter.

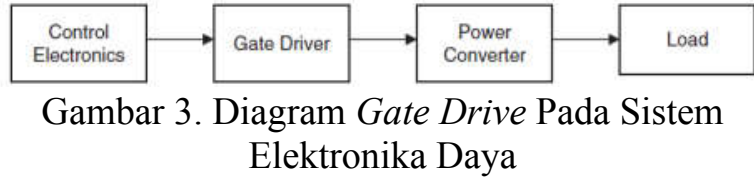

\section{B. Low Pass Filter}

Filter adalah suatu rangkaian elektronika yang dirancang untuk melewatkan frekuensi tertentu yang diinginkan dan menahan atau menghilangkan frekuensi selain frekuensi yang diinginkan tersebut. Dapat juga disebut dengan rangkaian pemilih frekuensi. Pada filter, terdapat istilah frekuensi cutoff, frekuensi ini lah yang membatasi frekuensi yang lebih tinggi atau yang lebih rendah dari sinyal masukan. Pada filter pasif ( disebut juga filter harmonisa) dapat mengurangi amplitudo tertentu dari tegangan ataupun arus.

Low pass filter adalah rangkaian filter yang bekerja dengan cara melewatkan frekuensi yang lebih rendah dari frekuensi cut-off dan menahan frekuensi yang lebih tinggi. Komponen pembentuk filter ini adalah resistor-kapasitor, resistor-induktor, induktor-kapasitor, ataupun ketiganya. Gambar 4 merupakan bentuk respon dari low pass filter.

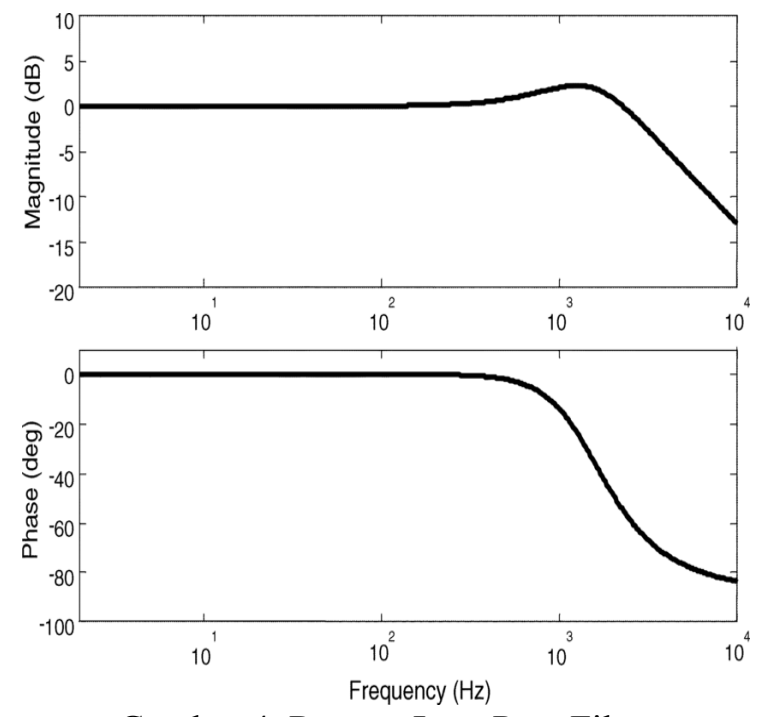

Gambar 4. Respon Low Pass Filter

\section{Komponen Utama Elektronika Daya}

Metal Oxide Semiconductor Field Effect Transistor (MOSFET) adalah sebuah komponen semikonduktor yang dapat digunakan sebagai saklar elektronik dan penguat sinyal pada perangkat elektronik. MOSFET umumnya memiliki 3 kaki, yaitu Gate (G), Drain (D), dan Source (S). Dari segi bahan semikonduktor pembuatnya, MOSFET terbagi atas 2 bagian yaitu MOSFET N-type dan MOSFET P-type.

MOSFET bekerja dengan cara memvariasikan 
lebar saluran muatan listrik. Muatan listrik masuk melalui saluran pada kaki source dan keluar melalui kaki drain. Lebar saluran muatan listrik divariasikan oleh gate, yang terisolasi oleh lapisan logam oksida yang tipis. Hal ini lah yang membuat MOSFET berbeda dengan transistor yang lain. Kegunaan dari MOSFET adalah untuk mengontrol arus dan tegangan yang melewati antara kaki source dan kaki drain.

IC IR2112 memiliki high dan low side output referensi yang masing masing berbeda. Ic ini memiliki logika pertukaran level yang dikombinasikan dengan sebuah amplifier. Dikarenakan ukuran ic yang sangat kecil dan kompleks, dapat menghemat ruang pada rangkaian yang akan diterapkan. IC ini, seringkali digunakan pada rangkaian yang berhungan dengan elektronika daya. Blok diagram IC IR2112 dapat dilihat pada gambar 5 .

Berbeda dengan IC optocoupler, IC ini memiliki built-in delay, sehingga jika sinyal output dari IC ini jika diterapkan pada komponen seperti IGBT ataupun MOSFET yang memiliki delay turnon dan turn-off, dapat membantu menghindari terjadinya short antara kaki-kaki komponen tersebut.

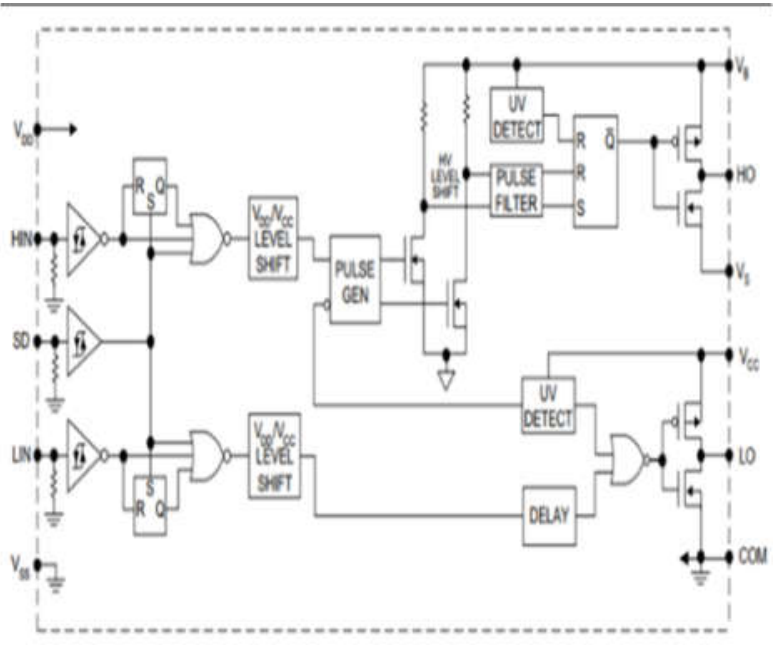

Gambar 5. Blok Diagram IC IR2112

\section{Arduino}

Arduino adalah perangkat mikrocontroler yang bersifat open source, yang menggunakan IC mikrokontroler ATMega sebagai komponen utamanya. Meskipun memakai IC dari AVR Atmel, namun pemograman arduino menggunakan bahasa pemograman tersendiri. Arduino juga berperan penting dalam pengendalian berbagai macam perangkat dan rangkaian elektronik, maupun untuk pengendalian berbagai macam motor. Arduino memiliki berbagai macam seri, salah satunya adalah Arduino Mega 2560. Pda gambar 6 dapat dilihat bentuk fisik Arduino Mega 2560.

Arduino Mega 2560 merupakan sebuah board mikrokontroller yang memiliki 54 pin digital input/output, dimana 14 pin sebagai pin PWM, 16 pin input analog, dan 4 pin sebagai UART ( port serial hardware ), sebuah $16 \mathrm{MHz}$ kristal osilator, sebuah koneksi USB, sebuah jack power untuk supply DC, sebuah header ICSP, dan sebuah tombol reset.

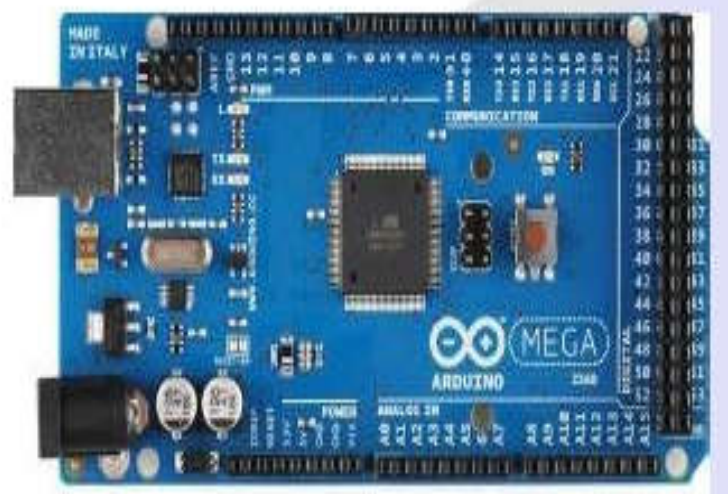

Gambar 6. Board Arduino Mega 2560

\section{E. Visual Basic. NET}

Visual Basic. NET atau disingkat VB. NET adalah sebuah software yang dikembangkan oleh Microsoft yang bertujuan untuk mendesain aplikasi dan antarmuka. Untuk merancang user interface, VB menyediakan pendekatan dalam bentuk form. Tujuan perancangan antar muka adalah untuk memudahkan hubungan komunikasi antara humanmachine. Pada gambar 7 dapat dilihat form tampilan $V B$ :

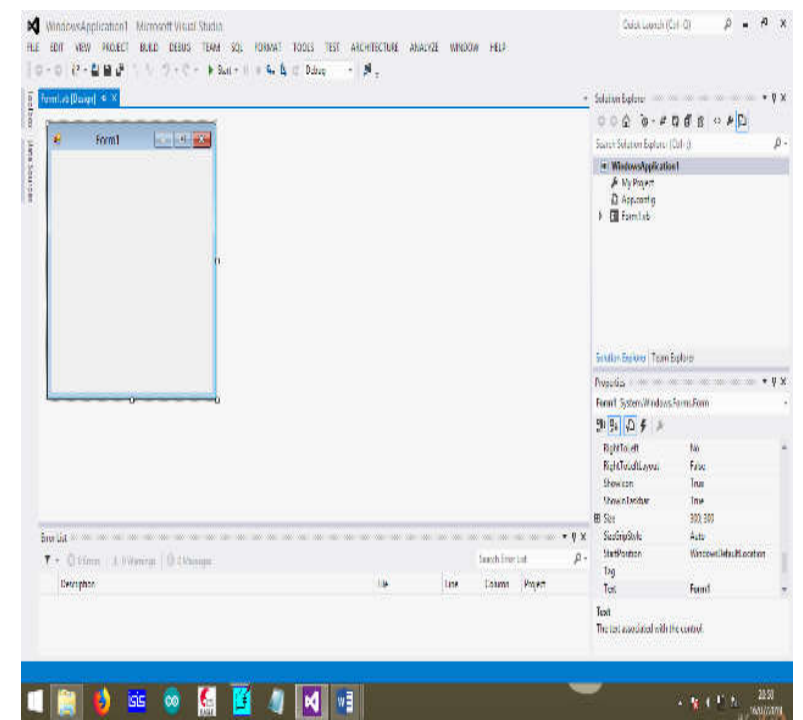

Gambar 7. Tampilan Desain Form Visual Basic 


\section{F. Motor Induksi}

Motor induksi atau disebut juga motor asinkron merupakan motor listrik yang kecepatan putarannya dibawah kecepatan rotasi medan magnetnya. Rotasi medan magnet tersebut dipengaruhi oleh frekuensi dan banyak kutub pada mesin. Putaran pada motor induksi dipengaruhi oleh terbangkitnya fluks pada rotor dikarenakan fluks medan magnet pada stator. Fasa-fasa pada motor dipisahkan sebesar $120^{\circ}$ listrik dan memiliki jumlah coil yang sama, serta terhubung dengan jumlah kutub yang sama pula [6].

Namun fluks pada rotor yang dibangkitkan, mengalami penundaan atau delay dibandingkan fluks yang dibangkitkan pada stator. Hal inilah yang menyebabkan kecepatan putar motor induksi berada dibawah kecepatan rotasi medan magnetnya. Berdasarkan supplai tegangan yang digunakan, motor induksi terbagi ke dua bagian, yaitu motor induksi 1 fasa dan 3 fasa. Konstruksi motor induksi tiga fasa dapat dilihat pada gambar 8 .
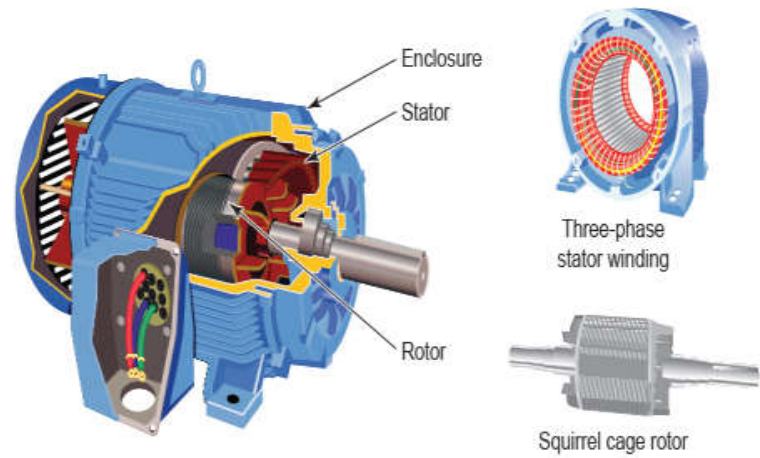

Gambar 8. Konstruksi Motor Induksi 3 Fasa

\section{G. Flowchart}

Pada gambar 9 diperlihatkan flowchart perancangan dan pembuatan inverter 3 fasa dengan metode SPWM untuk menggerakan motor induksi dengan konsep VVVF, dimana pengaturan besar tegangan dan frekuensi yang diinginkan dapat dikendalikan dengan mengubah besar tahanan potensiometer. Sinyal PWM yang dihasilkan dikirim ke rangkain gate drives yang berfungsi sebagai rangkaian pencatu dan pengisolasi rangkaian kendali dan rangkaian daya. Sinyal yang keluar dari rangkaian daya yang berupa arus dan tegangan tinggi menuju motor induksi tiga fasa yang dapat beroperasi sesuai dengan penyetelan yang diinginkan.

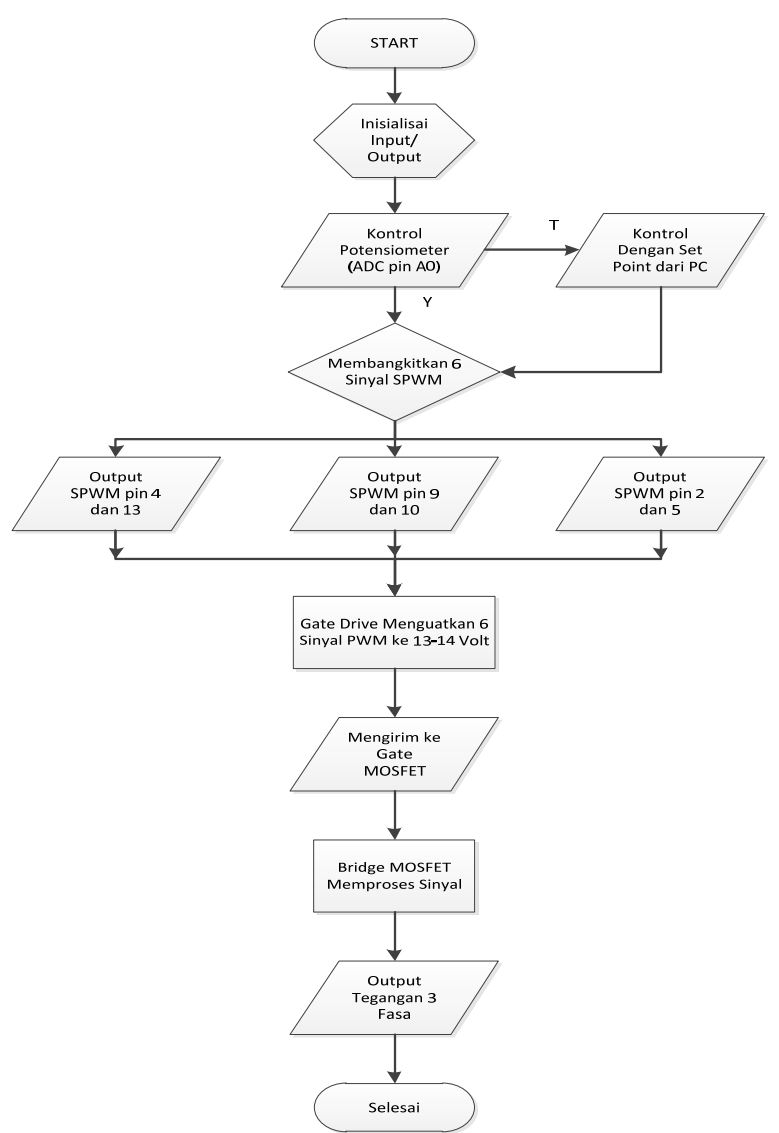

Gambar 9. Diagram alir system

\section{Metode Penelitian}

Pada awal perancangan alat, sebuah blok diagram hal pertama yang harus dibuat, hal ini bertujuan untuk mengetahui prinsip kerja dari alat secara keseluruhan. Blok diagram inilah yang nantinya mempermudah proses tahapan dari alat dan pemrosesan apa saja yang terlibat. Juga untuk mengobservasi dimanakah error dari alat apabila alat mengalami kerusakan. Blok diagram alat yang dirancang dapat dilihat pada gambar 10 .

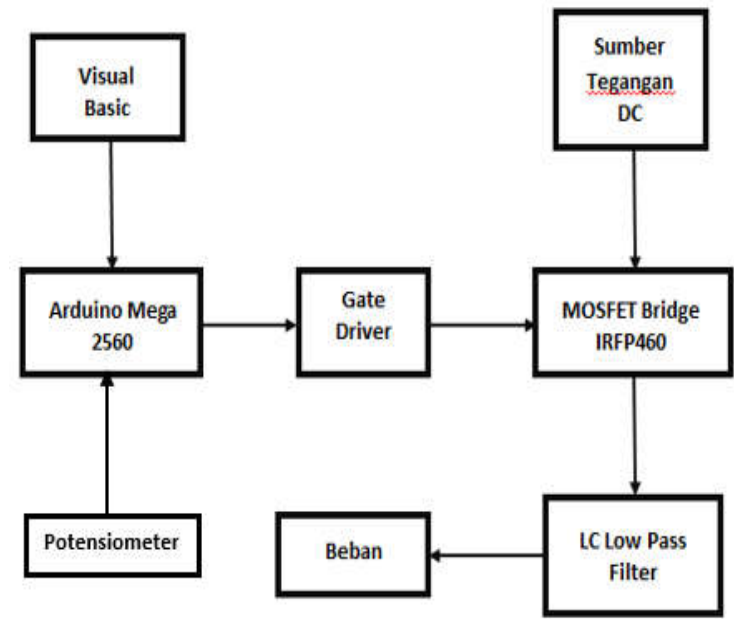

Gambar 10. Blok diagram alat 
Fungsi dari masing-masing bagian blok diagram yaitu:

1. Arduino Uno berfungsi sebagai penghasil sinyal SPWM yang nantinya akan diteruskan ke gate driver, dan pengkomunikasian data ke PC.

2. Gate driver berfungsi sebagai penghasil tegangan uang dapat diterima MOSFET sehingga MOSFET dapat bekerja dengan baik.

3. MOSFET Bridge berfungsi sebagai pengasil keluaran AC

4. Sumber tegangan DC sebagai pemasok tegangan DC ke rangkaian MOSFET

5. LC Low Pass Filter sebagai filter keluaran dari rangkaian MOSFET, sehingga gelombang yang dikeluarkan dapat berupa sinus

6. Beban disini berupa motor induksi 3 fasa, yang nantinya dapat divariasikan kecepatannya

7. PC digunakan sebagai antarmuka untuk pengoperasian motor yang dilakukan dengan software VB.Net

8. Potensiometer digunakan sebagai kontrol analog untuk memvariasikan kecepatan motor

\section{Hasil dan Pembahasan}

Pada gambar 11 diperlihatkan rangkaian peralatan dan purwarupa inverter tiga fasa yang dirancang serta diujicoba pada motor induksi tiga fasa.

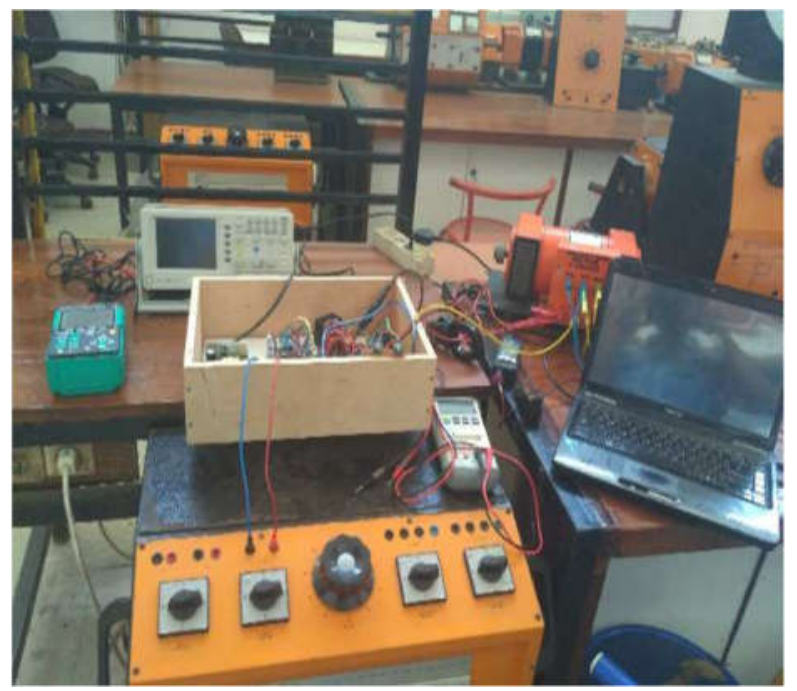

Gambar 11. Rangkaian pengujian purwarupa

\section{A. Pengujian Catu Daya}

Pada pengujian catu daya, dilakukan untuk melihat keluaran catu daya beserta modul buckboost. Hasil keluaran yang diharapkan dari pengujian catu daya dan modul buck-boost ada 2 tegangan, yaitu $12 \mathrm{vdc}$ dan $5 \mathrm{vdc}$. Kedua tegangan tersebut berfungsi menyupplai arduino mega2560, rangkaian gate driver, sensor arus, dan sensor tegangan. Tabel 1 menyajikan pengukuran catu daya.

Tabel 1. Pengujian Catu Daya

\begin{tabular}{|c|c|c|}
\hline No. & Parameter Pengukuran & Nilai \\
\hline 1 & Tegangan AC (PLN) & $220 \mathrm{~V}$ \\
\hline 2 & Tegangan catu daya & $12,184 \mathrm{Vdc}$ \\
\hline 3 & Tegangan buck-boost & $5,056 \mathrm{Vdc}$ \\
\hline
\end{tabular}

Dapat dilihat untuk keluaran catu daya dan buck-boost, mendapatkan keluaran 12,184 vdc dan 5,056 vdc. Keluaran yang diperoleh ini cukup ideal untuk di supplai ke arduino mega2560, gate driver, sensor arus dan sensor tegangan.

\section{B. Pengujian input dan output Arduino Atmega328}

Arduino Mega2560 memiliki tegangan kerja sebesar 5Vdc. Dan memiliki dua kondisi yaitu high dan low. Pada tabel 2 merupakan hasil pengujian pin logika pada Arduino Mega2560, diantaranya :

Tabel 2. Pengujian Atmega328

\begin{tabular}{|c|c|}
\hline Logika Port & Tegangan pada pin I/O \\
\hline Low (0) & $0,005 \mathrm{~V}$ \\
\hline High (1) & $4,947 \mathrm{~V}$ \\
\hline
\end{tabular}

Tabel 3. Pegujian Pin ADC Arduino

\begin{tabular}{|c|c|c|c|}
\hline $\begin{array}{c}\text { Tegangan } \\
\text { input }\end{array}$ & $\begin{array}{c}\text { Data ADC } \\
\text { seharusnya }\end{array}$ & $\begin{array}{c}\text { Daya yang } \\
\text { terukur }\end{array}$ & $\begin{array}{c}\text { Galat } \\
\%\end{array}$ \\
\hline 0,1 & 20,46 & 20 & 2,24 \\
\hline 0,5 & 102,3 & 103 & 0,6 \\
\hline 1,3 & 256,98 & 258 & 0,39 \\
\hline 1,9 & 388,7 & 390 & 0,33 \\
\hline 2,4 & 491,04 & 492 & 0,19 \\
\hline 2,8 & 572,8 & 573 & 0,13 \\
\hline 3,3 & 675,1 & 676 & 0,13 \\
\hline 3,7 & 757,02 & 758 & 0,12 \\
\hline 4,5 & 920,7 & 921 & 0,03 \\
\hline 5 & 1023 & 1023 & 0 \\
\hline
\end{tabular}

\section{Pengujian Analog Digital Converter Arduino Uno}

Pengujian ADC pada arduino diperlukan karena menjadi bagian yang penting dalam pengkonversial data analog ke data digital. Dengan tegangan referensi $5 \mathrm{~V}$, maka untuk 1 desimal nilai ADC sebesar $4,88 \mathrm{mV}$. Dari nilai ninilah dapat dijadikan acuan baik tidaknya ADC pada arduino. 
Untuk pengujian, tegangan sebesar $0-5 \mathrm{~V}$ diberikan ke pin analog. Hasil konversi dapat dilihat di serial monitor Arduino IDE. Pada tabel 3 ditampilkan hasil pengujian ADC arduino Mega2560.

\section{Pengujian gate driver}

Pengujian rangkaian gate driver dilakukan dengan melihat gelombang keluaran pada pin high dan low. Masukan dari gate driver adalah pin 2, 4, 5, 9, 10, dan 13 Arduino Mega2560. Keluaran dari gate driver inilah yang nantinya akan mengatur unjuk kerja dari gate MOSFET. Pada tabel 4 disajikan pengukuran rangkaian gate drives

Tabel 4. Pengukuran Rangkaian Gate Drive

\begin{tabular}{|c|c|c|c|c|c|}
\hline \multicolumn{2}{|c|}{ A } & \multicolumn{2}{c|}{ B } & \multicolumn{2}{c|}{ C } \\
\hline High & low & High & low & High & low \\
\hline 3,61 & 3,75 & 3,60 & 3,77 & 3,59 & 3,71 \\
\hline
\end{tabular}

Untuk gelombang keluaran dari gate driver IR2110, dapat dilihat pada gambar $12-14$.

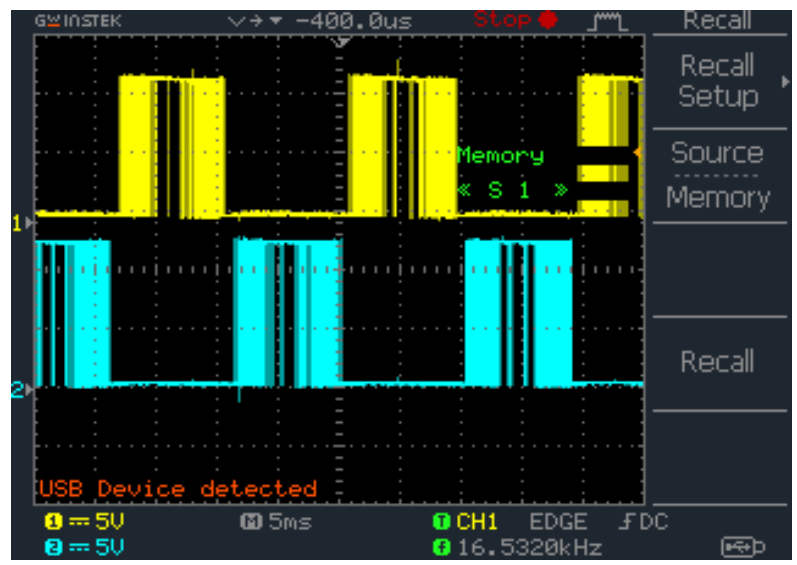

Gambar 12. Sinyal gate driver untuk fasa A

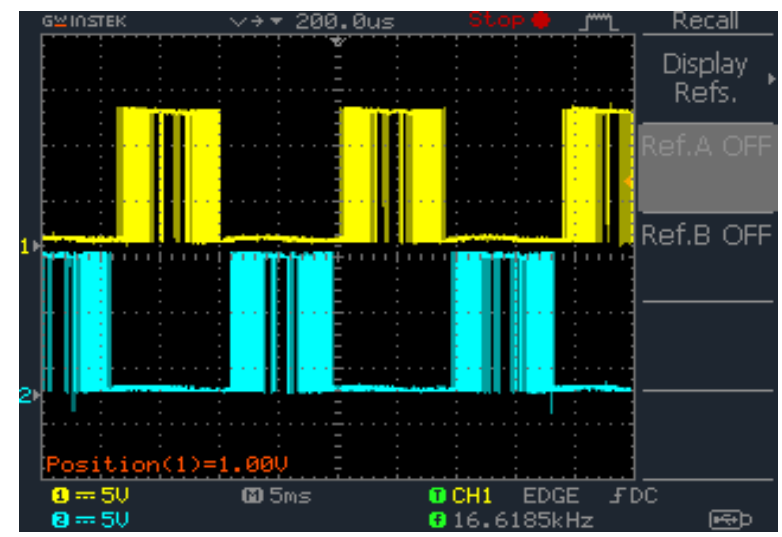

Gambar 13. Sinyal gate driver untuk fasa B

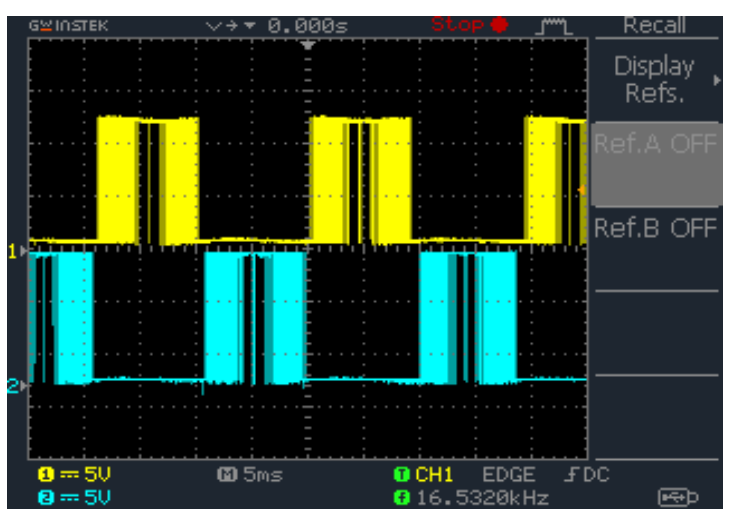

Gambar 14. Sinyal gate driver untuk fasa $\mathrm{C}$

\section{E. Pengujian Rangkaian Secara Keseluruhan Tanpa Beban}

Untuk pengujian tanpa beban, tegangan masukan dc akan divariasikan dari 20 - $220 \mathrm{vdc}$, dengan frekuensi keluaran di set ke $50 \mathrm{~Hz}$ dan potensiometer untuk tegangan di set ke maksimum. Tegangan sumber dc di supplai dari sebuah powerpack. Pada tabel 5 disajikan pengukuran rangkaian keseluruhan tanpa beban

Tabel 5. Pengukuran Tanpa Beban

\begin{tabular}{|c|c|c|c|c|c|}
\hline \multirow{2}{*}{$\begin{array}{c}\text { Masukan } \\
\text { DC } \\
\text { (Vdc) }\end{array}$} & \multicolumn{3}{|c|}{ Tegangan Keluaran Antar } & $\begin{array}{c}\text { Tegan } \\
\text { gan } \\
\text { Fasa- } \\
\text { Fetral } \\
\text { (Vac) }\end{array}$ & $\begin{array}{c}\text { Frekuensi } \\
(\mathrm{Hz})\end{array}$ \\
\hline 20 & 16,38 & 14,83 & 15,42 & 9,09 & $50 \mathrm{~Hz}$ \\
\hline 50 & 37,73 & 34,10 & 35,28 & 21,06 & $50 \mathrm{~Hz}$ \\
\hline 70 & 51,35 & 46,55 & 48,14 & 28,54 & $50 \mathrm{~Hz}$ \\
\hline 100 & 71,62 & 64,62 & 66,75 & 39,66 & $50 \mathrm{~Hz}$ \\
\hline 120 & 81,25 & 72,26 & 73,55 & 45,37 & $50 \mathrm{~Hz}$ \\
\hline 150 & 95,77 & 88,51 & 84,95 & 54,42 & $50 \mathrm{~Hz}$ \\
\hline 170 & 106,18 & 99,14 & 95,20 & 60,59 & $50 \mathrm{~Hz}$ \\
\hline 200 & 118,27 & 118,16 & 109,71 & 72,29 & $50 \mathrm{~Hz}$ \\
\hline 220 & 129,11 & 124,85 & 112,53 & 76,54 & $50 \mathrm{~Hz}$ \\
\hline
\end{tabular}

Pada gambar 15-17 disajikan bentuk gelombangtegangan keluaran dari pengukuran tanpa beban.

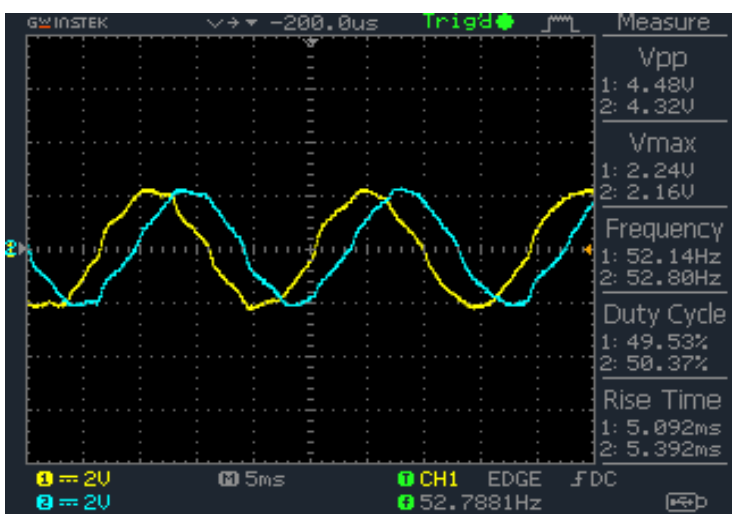

Gambar 15. Tegangan Fasa-Fasa RS dan ST 


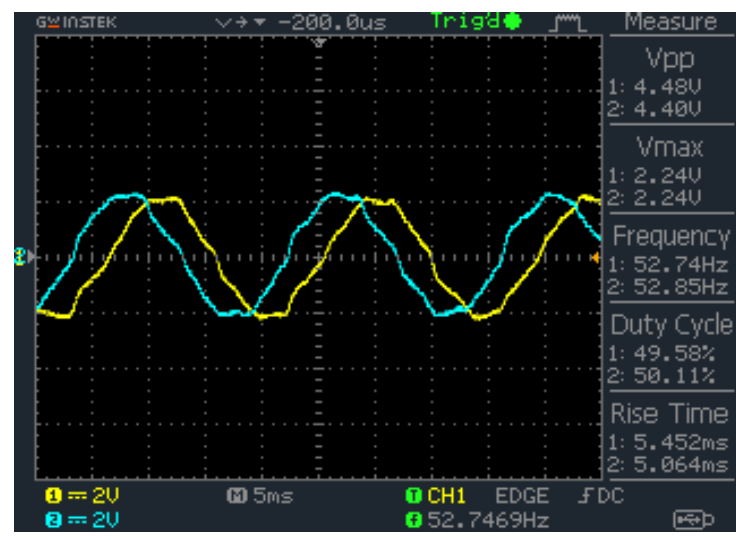

Gambar 16. Tegangan Fasa-Fasa RS dan RT

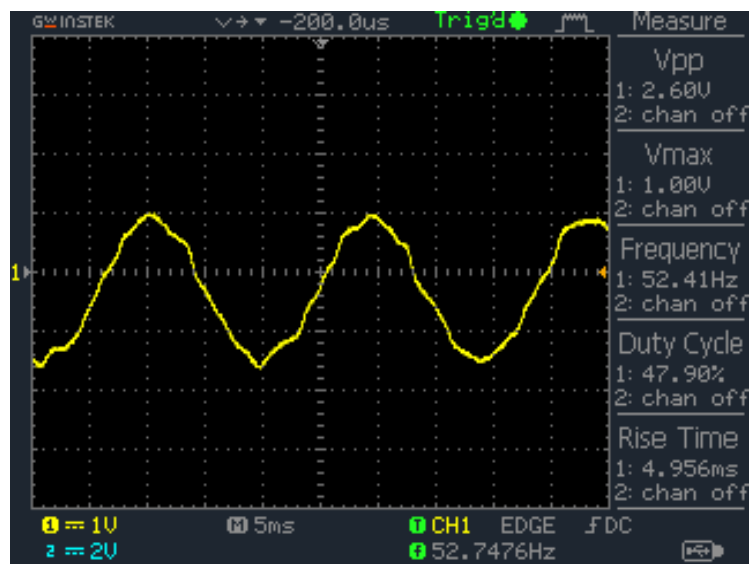

Gambar 17. Tegangan Keluaran Fasa-Netral

\section{F. Pengujian Rangkaian Secara Keseluruhan Berbeban}

Pengukuran dengan dilakukan dengan memberi sebuah beban berupa motor induksi 3 fasa, bertujuan untuk melihat apakah ada pengaruh tegangan inverter jika diberikan beban, dan apakah frequensi berpengaruh terhadap kecepatan motor. Berikut ini adalah tabel pengujian keluaran inverter berbeban dengan tegangan masukan di set $230 \mathrm{Vdc}$ dan frekuensi divariasikan dari $10-50 \mathrm{~Hz}$, sedang pot tegangan di set ke maksimum.

Pada gambar 18-20 disajikan hasil monitoring pada software VB.Net.

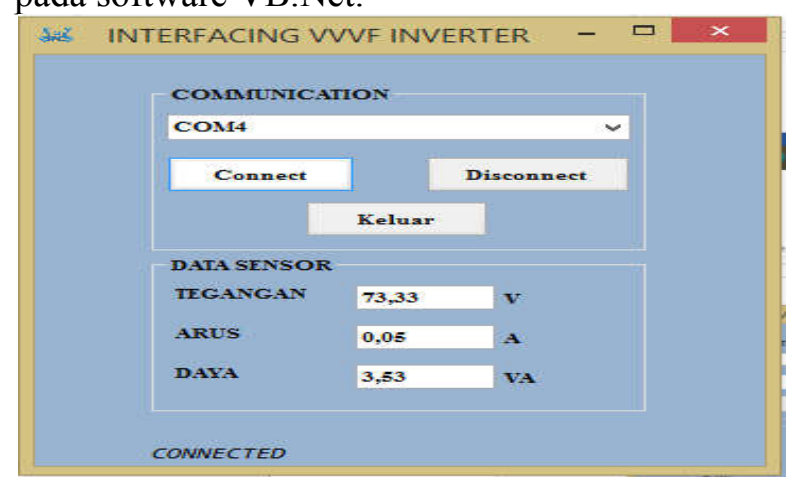

Gambar 18. Monitoring Untuk Frekuensi 10 Hz

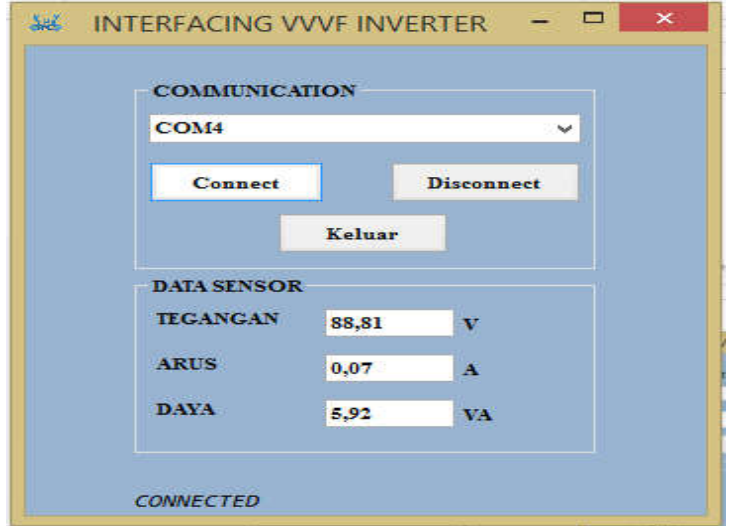

Gambar 19. Monitoring Frekuensi $20 \mathrm{~Hz}$

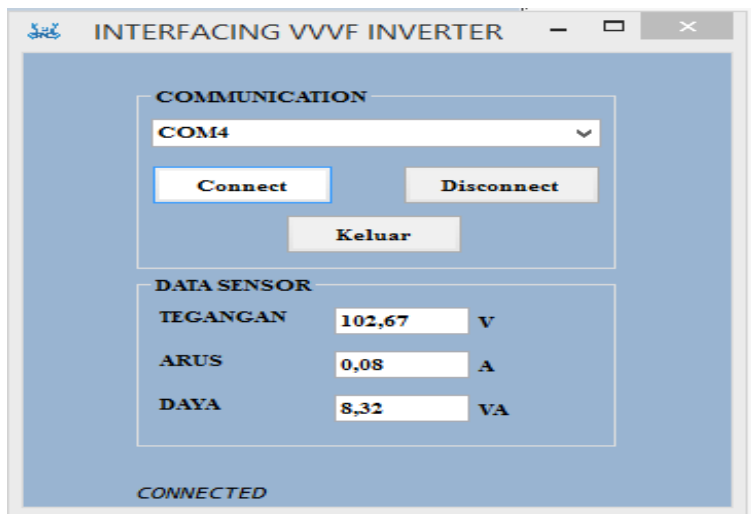

Gambar 20. Monitoring Untuk Frekuensi $50 \mathrm{~Hz}$

\section{KeSIMPULAN}

Berdasarkan hasil dari pengujian dan analisa pada input dan output pada rancangan tugas akhir dapat disimpulkan perubahan frekuensi pada output inverter, didasarkan dari penyempitan atau pelebaran nilai-nilai duty cycle pada lookup table. Contohnya untuk mendapatkan frekuensi rendah, nilai variabel dari duty cycle tersebut harus melompat melewati variabel didekatnya, seperti 1 yang seharusnya bergeser ke 2, malah melompat ke 3. Hal ini akan membuat frekuensi keluaran akan semakin mengecil.

Untuk frekuensi tertentu, nilai lompatan tersebut dapat disesuaikan. Sedangkan untuk mendapatkan nilai amplitudo tegangan yang bervariasi, dilakukan dengan mengubah besarnya nilai seluruh variable duty cycle yang ada pada lookup table. Untuk output dari inverter sesudah difilter, masih belum berbentuk sinusoidal murni, dikarenakan komponen filter dan frekuensi cut-off yang digunakan tidak sesuai. Frekuensi cut-off yang seharusnya harus berada pada $500-1500 \mathrm{~Hz}$ untuk mendapatkan hasil yang maksimal.

Pada monitoring dengan software VB.Net, dapat dilihat nilai tegangan dan arus berbeda dengan nilai pengukuran, hal ini dikarenakan 
resolusi dari sensor arus dan tegangan yang begitu kecil, sehingga tidak bisa membaca pengukuran arus dan tegangan dengan tepat.

\section{DAfTAR PUSTAKa}

[1] Dokic, Branko L., Branko Blanusa. (2015). Power Electronics: Converter and Regulator. ( $\left.3^{\text {rd }} \mathrm{ed}\right)$. Berlin: Springer.

[2] Hart, Daniel W. (2011). Power Electronics. New York: McGraw-Hill.

[3] Petruzella, Frank D. (2010). Electric Motors and Control Systems. New York: McGraw-Hill.

[4] Trzynadlowski, Andrzej. (2016). Introduction to Modern Power Electronics. (3rd ed). New Jersey: John Wiley \& Sons.

[5] Mohan, Ned, Tore M. Undeland, and William P. Robbins. (1995). Power Electronics. (2nd ed). New Jersey: John Wiley \& Sons.

[6] Oby, Zamisyak. (2017). Basic Arduino \#1. Yogyakarta: Indobot Robotic Center.

[7] Rashid, Muhammad H. (2008). Power Electronics: Circuits, Devices, and Applications. (3rd ed.). New Jersey. Prentice Hall.

[8] Rozanov, Yuriy, et al. (2016). Power Electronics Basics: Operating Principles, Design, Formulas, and Applications. Boca Raton: Taylor \& Francis Group.

\section{Biodata Penulis}

Fitrah Hidayat, dilahirkan di Sungai Kambut, 17 Juni 1996. Menyelesaikan DIV Teknik Elektro Industri pada jurusan Teknik Elektro Fakultas Teknik Universitas Negeri Padang.

Krismadinata, dilahirkan di Padang pada tanggal 11 September 1977. Lulus dengan gelar Sarjana Tenik dari Universitas Andalas pada tahun 2000. Memperoleh gelar Magister Teknik dari Institut Teknologi Bandung (ITB) pada tahun 2004, dan S3 di Universiti Malaya Kuala Lumpur pada tahun 2012. 
